\title{
ANALISIS HAMBATAN KUALITAS SISTEM INFORMASI AKUNTANSI PERBANKAN DI ERA INDUSTRI 4.0
}

\author{
Rapina \\ rapinacen@yahoo.com \\ Hanny \\ Fakultas Bisnis, Universitas Kristen Maranatha, Bandung \\ Nunuy Nur Afiah \\ FEB, Universitas Padjajaran, Bandung
}

\begin{abstract}
The fourth Industrial Revolution significantly changed banking products and services. The bank needs relevant and quality accounting information to support them in providing products and services to customers. The required accounting information is generated from an accounting information system owned by each bank. The purpose of this research is to determine how much the independent variables can influence the successful implementation of the accounting information system in banking. There are three independent variables analyzed, namely personality characteristics, organizational structure and quality of business processes. The results of this study are expected to be useful for banks in implementing strategies when managing the quality of accounting information systems that will produce quality accounting information. The type of data used in this study is primary data obtained through distributing questionnaires to 46 banking companies in Indonesia. Verification analysis was performed using the SEM-PLS test tool. The results showed that problems in the quality of accounting information were caused by the application of accounting information systems that were not maximally integrated. Furthermore, it was found that the application of accounting information systems in banking organizations must be able to accommodate personality characteristics, organizational structure and quality of business processes.
\end{abstract}

Key words: banking accounting information systems, industri 4.0, quality of accounting information, quality of accounting information systems.

\begin{abstract}
ABSTRAK
Revolusi Industri keempat secara signifikan mengubah produk dan layanan perbankan. Bank itu membutuhkan informasi akuntansi yang relevan dan berkualitas untuk mendukung mereka dalam memberikan produk dan jasanya kepada nasabah. Informasi akuntansi yang diperlukan tersebut dilahirkan dari sebuah sistem informasi akuntansi yang dimiliki oleh masing-masing perbankan. Maksud diadakannya penelitian ini untuk mengetahui seberapa besar variabel-variabel bebas dapat mempengaruhi keberhasilan implementasi sistem informasi akuntansi pada perbankan. Terdapat 3 variabel bebas yang dianalisis, yaitu karakteristik kepribadian, struktur organisasi dan kualitas proses bisnis. Hasil penelitian ini diharapkan akan bermanfaat bagi bank dalam melakukan strategi ketika mengelola kualitas sistem informasi akuntansi yang akan memproduksi kualitas informasi akuntansi. Jenis data yang dipakai dalam penelitian ini adalah data primer yang diperoleh melalui penyebaran kuesioner kepada 46 perusahaan perbankan di Indonesia. Analisis verifikatif dilakukan dengan menggunakan alat uji SEM-PLS. Hasil penelitian menunjukkan bahwa masalah-masalah dalam kualitas informasi akuntansi disebabkan oleh penerapan sistem informasi akuntansi yang belum terintegrasi secara maksimal. Lebih lanjut ditemukan bahwa aplikasi sistem informasi akuntansi pada organisasi perbankan harus dapat mengakomodir karakteristik kepribadian, struktur organisasi dan kualitas proses bisnis.
\end{abstract}

Kata kunci: sistem informasi akuntansi perbankan, industri 4.0, kualitas informasi akuntansi, kualitas sistem informasi akuntansi. 


\section{PENDAHULUAN}

Negara kita mulai memasuki masa Revolusi Industri 4.0 sejak tahun 2011 (Hartarto, 2018). Penerapan digitalisasi yang menjadi salah satu ciri khas dari era Revolusi Industri 4.0 ini telah mengubah cara kerja manusia. Mereka dapat bekerja dengan dukungan proses operasi yang lebih efisien dan cerdas (Huy dan Phuc, 2020). Di bidang perbankan, digitalisasi mengubah kebutuhan para konsumennya sehingga bank dengan gesit harus membenahi model bisnisnya agar dapat memenuhi permintaan konsumennya. Mereka perlu berupaya untuk melakukan kerjasama dengan perusahaan FinTech serta perlu memikirkan pengembangan komponen Era Industri 4.0 lainnya seperti: kecerdasan buatan, blockchain, big data dan lain-lain. Di sisi lain, sejalan dengan perkembangan model bisnisnya yang semakin kompleks ini, bank tetap wajib menjaga keamanan dan keandalan datanya, khususnya yang berkaitan dengan data konsumen/nasabahnya (Mekinjić, 2019). Tidak heran jika perbankan berusaha untuk menginvestasikan dananya untuk memiliki software sebagai salah satu upaya untuk mengembangkan sistem informasi akuntansi yang dilengkapi dengan teknologi informasi secara mumpuni (Okab dan Al-Oqool, 2014).

Implementasi sebuah sistem informasi akuntansi yang mumpuni/berkualitas merupakan hal yang tidak sederhana dan seringkali berhadapan dengan pelbagai kendala. Di Indonesia, sistem informasi yang digunakan dalam organisasi masih mengalami kendala, contohnya saat meninjau integrasi sistem antar organisasi yang terkait, Ketua Mahkamah Konstitusi, Hidayat (2015) menyarankan pembuatan sistem informasi yang terintegrasi bagi BI, OJK, dan LPS, dimana ketiganya merupakan lembaga pengawas perbankan. Belum terintegrasinya sistem antar ketiga lembaga ini akan menimbulkan risiko informasi yang saling tumpang tindih dan menutup kemungkinan bagi ketiga lembaga ini untuk saling berbagi informasi.
Informasi yang dihasilkan oleh Sistem Informasi Akuntansi (SIA) saat ini adalah penentu keberhasilan perusahaan karena SIA memiliki peranan dalam membantu organisasi menyerap dan mempertahankan peluang strategis (Ramazani dan Allahyari, 2013). Keberhasilan sistem informasi dan faktor-faktor yang mempengaruhinya telah dianggap penting untuk bidang sistem informasi. Salah satu faktor yang harus diperhatikan agar tercapai kesuksesan dalam implementasi sistem adalah kepribadian (Barnet et al., 2015). Penelitian Dehghanzade et al. (2011) menunjukkan bahwa kepribadian tertentu akan mempengaruhi efektivitas sistem informasi akuntansi. Temuan empiris lain yang dilakukan oleh Rapina dan Susanto (2017) menemukan bahwa faktor kepribadian dari user akan mempengaruhi sistem informasi yang berkualitas dengan cara memberikan pelatihan terhadap user agar user lebih menerima penggunaan sistem informasi dalam melakukan pekerjaannya. Fenomena yang baru terjadi terkait faktor kepribadian ini adalah kasus keterlibatan oknum pegawai bank dalam pembobolan rekening Ilham Bintang seperti yang diungkapkan oleh Velarosdela (2020). Dalam kasus ini, Hendri yang adalah seorang pegawai BPR Bintara Pratama Sejahtera melakukan penjualan data nasabah dengan menggunakan Sistem Laporan Informasi Keuangan Otoritas Jasa Keuangan (OJK). Dalam kasus ini tampak bahwa kepribadian Hendri ini membawa pengaruh negatif terhadap keberhasilan SIA di perbankan.

Faktor lain yang dapat mempengaruhi keberhasilan sebuah sistem informasi akuntansi adalah struktur organisasi (Rahayu, 2012b; Rapina, 2017; Fransisca et al., 2020). Triyaminanti (2017) menyatakan bahwa SIA dapat saja mengalami perubahan dimana perubahan ini sangat bergantung pada struktur organisasinya. Hasil penelitiannya menunjukkan bahwa struktur organisasi berpengaruh positif terhadap kualitas SIA. Di sisi lain, menurut Salehi dan Abdipour (2013), faktor struktur organisasi dapat saja menjadi kendala bagi keberhasilan sistem 
informasi akuntansi. Kasus kegagalan sistem informasi akuntansi yang bahkan berbasis ERP pernah dialami oleh perusahaan besar sekelas FoxMeyer (Gross, 2011). Menurut artikel yang ditulis oleh Gross (2011), kegagalan dalam penerapan sistem informasi ini dapat dihindari, salah satunya dengan membangun struktur tim proyek sistem yang kuat. Oleh karena itu, untuk bergerak menuju bisnis digital akan membutuhkan organisasi untuk menjalani transformasi sosio-teknis besar-besaran yang dipengaruhi oleh struktur organisasi, strategi, arsitektur TI, metode, dan model bisnis (Legner et al., 2017).

Kualitas sebuah proses bisnis merupakan faktor lain yang dapat mempengaruhi kualitas SIA (Ruiz et al., 2015; Sari, 2018b; Huang et al, 2015; Trigo et al., 2016). Hasil penelitian yang pernah dilakukan menunjukkan bahwa organisasi dapat meningkatkan kualitas sistem informasinya melalui pengembangan proses bisnis yang baik (Meiryani dan Syaifullah, 2015). Hal ini sejalan dengan hasil penelitian Rapina dan Hadianto (2019) pada 61 responden perbankan di Indonesia. Lebih lanjut, hasil penelitian Rapina dan Hadianto (2019) tersebut mengungkapkan bahwa kualitas SIA berpengaruh positif terhadap kualitas informasi akuntansi.

Berdasarkan uraian di atas, menarik untuk diteliti lebih jauh apakah dengan memperhatikan karakteristik kepribadian, struktur organisasi yang kuat dan proses bisnis yang baik secara bersamaan akan berpengaruh terhadap peningkatan kualitas sistem informasi akuntansi di perbankan, mengingat industri perbankan memiliki peranan yang signifikan terhadap pemerataan dan pertumbuhan ekonomi seperti yang diungkapkan oleh Menteri Keuangan Republik Indonesia saat ini (Mulyani, 2018). Untuk memperlengkapi hasil, penelitian ini juga akan menguji pengaruh kualitas sistem informasi akuntansi terhadap kualitas informasi akuntansi perbankan.

Penelitian terdahulu belum menggabungkan 3 (tiga) variabel independen yang digunakan yaitu karakteristik kepribadian, struktur organisasi dan proses bisnis menjadi 3 variabel independen yang mempengaruhi variabel dependen dan hal tersebut merupakan kebaruan dalam model penelitian pada kesempatan ini. Temuan penelitian ini diharapkan dapat membantu para praktisi yang hendak merancang strategi peningkatan kualitas sistem informasi akuntansi dan kualitas informasi di organisasinya dengan cara meningkatkan kesadaran mereka akan 3 (tiga) faktor yang dapat mendukung atau menghambat keberhasilan mereka saat menerapkan sistem informasi akuntansinya.

\section{TINJAUAN TEORETIS}

\section{Sistem Informasi Akuntansi (SIA) dan Era Revolusi Industri 4.0}

SIA adalah himpunan orang dan perangkat sebagai sumber daya yang mengonversikan data menjadi informasi bagi seluruh tingkat administrasi dengan tujuan perencanaan dan pengendalian perusahaan dan para pemangku kepentingannya yang dipengaruhi oleh perkembangan teknologi informasi (Huy dan Phuc, 2020). Sejak Era Industri 4.0 muncul pertama kalinya di Jerman, keberadaan big data sebagai salah satu komponen industri 4.0 ini berdampak signifikan terhadap akuntansi.

Big data dapat membantu perusahaan di bidang akuntansi manajerial, khususnya untuk melaksanakan perencanaan dan pengendalian manajemen. Big data ini juga membantu perusahaan di bidang akuntansi keuangan, khususnya dalam hal menunjang organisasi saat hendak menyediakan informasi akuntansi yang lebih berkualitas dan transparan. Big data ini juga akan mempengaruhi prinsip akuntansi berlaku umum serta mendorong para akuntan untuk menyediakan data yang real time (Warren et al., 2015).

\section{Kualitas Proses Bisnis Dalam Kualitas SIA}

Proses bisnis yang dimiliki sebuah organisasi memberikan pengaruh pada bidang sistem informasi (Asllani dan Ali, 
2011; Dwivedi et al., 2014; Heinrich et al., 2017; Sari, 2018b; Endraria, 2019, Effendi dan Nuzulita, 2019). Penelitian yang menganalisis keberhasilan sistem informasi dan implementasi proses bisnis perlu dilakukan dalam rangka berkontribusi terhadap penelitian-penelitian dalam sistem informasi (Laumer et al, 2014). Belfo dan Trigo (2013) dalam studi empirisnya menyatakan bahwa proses bisnis dengan fungsionalitas alur kerja yang terintegrasi dalam sistem informasi akuntansi akan memfasilitasi analytic accounting dan pelaporan yang tepat waktu karena memungkinkan analisis proses secara detail, membantu alokasi biaya dan pendapatan ke dalam biaya yang lebih spesifik atau pusat pendapatan.

Hal senada dikatakan oleh Huang et al. (2015) dalam temuan empirisnya yang menyimpulkan bahwa terdapat hubungan positif antara investasi dalam sistem informasi dan teknologi informasi dengan proses bisnis yang diterapkan. Penelitian selanjutnya dilakukan oleh Trigo et al. (2016) yang juga menyatakan bahwa ada pengaruh proses bisnis terhadap sistem informasi akuntansi dimana implementasi proses bisnis beberapa tahun terakhir telah membuat evolusi pada sistem informasi akuntansi sehingga membuat akuntansi harus dapat mengakomodir proses bisnis yang terjadi.

Penelitian yang dilakukan oleh Sari (2018b) pada BUMN di Kota Bandung menguji proses bisnis terhadap kualitas sistem informasi akuntansi menyimpulkan bahwa proses bisnis memiliki pengaruh terhadap kualitas sistem informasi akuntansi. Sistem informasi akuntansi menjadi penting untuk memberikan informasi yang dibutuhkan pengguna agar mengurangi ketidakpastian, mendukung keputusan, dan mendorong penjadwalan, dan pengendalian pekerjaan dengan lebih baik. Laumer et al. (2014) melakukan studi empiris tentang proses bisnis dan sistem informasi sumber daya manusia pada penyedia jasa keuangan. Hasilnya berkontribusi pada penelitian sistem informasi karena menggambarkan bagaimana gabungan proses bisnis dan sistem informasi dapat diimplementasikan dalam proses layanan sekunder dan memberikan bukti untuk efek positif proses bisnis dan sistem informasi sumber daya manusia. Selanjutnya Meiryani dan Syaifullah (2015) juga menemukan bahwa Kualitas Sistem Informasi Akuntansi dipengaruhi oleh proses bisnis dalam penelitiannya menggunakan data sekunder dan menyimpulkan bahwa Kualitas SIA dapat diperbaiki melalui penerapan proses bisnis yang baik.

$\mathrm{H}_{1}$ : Kualitas Proses Bisnis mempengaruhi kualitas SIA.

\section{Karakteristik Kepribadian Dalam Kualitas SIA}

Barnet et al. (2015) dalam studinya mengatakan bahwa memahami adopsi dan penggunaan teknologi sangat penting di bidang sistem informasi dengan mengeksplorasi peran kepribadian dengan five factor model of personality. Maier (2012) juga pernah melakukan penelitian tentang hal tersebut mengenai variabel kepribadian dalam sistem informasi dengan menganalisis 30 artikel yang membahas karakteristik kepribadian dan menemukan hasil bagaimana cara menyusun tim kerja agar kinerjanya maksimal ketika dihadapkan dengan penerapan sistem informasi. Menyambung hal tersebut Kabugo (2011) dalam studinya pada universitas di Uganda terhadap 244 dosen dari enam fakultas melaporkan bahwa sikap dosen akan berubah terhadap pemanfaatan sistem informasi sesuai dengan tipe kepribadian, sehingga disimpulkan bahwa kepribadian akan mempengaruhi sistem informasi yang digunakan. Penelitian yang dilakukan oleh Lea et al., (2019) menyimpulkan bahwa lima karakteristik kepribadian yaitu openness, interaksi openness dan agreeableness, interaksi openness, agreeableness, dan conscientiousness, interaksi openness, agreeableness, dan extraversion, serta interaksi openness dan extraversion secara statistik signifikan mempengaruhi kinerja sistem informasi. 
Faktor-faktor yang mendukung keberhasilan suatu proyek teknologi informasi adalah anggota tim yang kompeten, motivation yang baik, pengetahun manajer yang mumpuni, gaya manajemen yang adaptif dan memiliki superior customer relationship (Taherdoost dan Varzsaleh, 2015). Dehghanzade et al. (2011) melakukan penelitian mengenai pengaruh human factor terhadap efektivitas sistem informasi akuntansi di 62 kantor organisasi sektor publik dan perusahaan swasta yang menggunakan SIA secara terkomputerisasi. Hasil penelitian adalah bahwa karakteristik personal yang terdiri dari keterbukaan, keramahan dan juga kepuasan kerja, pengalaman bekerja dengan software keuangan memiliki pengaruh terhadap efektivitas SIA berbasis komputer. Khan et al. (2014) melakukan studi utuk membangun sebuah model berdasarkan studi sebelumnya untuk menemukan pengaruh signifikan dari personality terhadap model penerimaan teknologi pada periode adopsi teknologi. Hasil studi menunjukkan bahwa 3 item personality termasuk openness, conscienciousness dan extraversion memiliki pengaruh yang kuat terhadap Technology Acceptance Model (TAM). Studi empiris yang juga menggali tentang karakteristik kepribadian mempengaruhi implementasi sistem informasi pernah dilakukan oleh Kosti et al. (2014); Yilmaz et al. (2017); Lakhal dan Khechine (2017) serta Khechine dan Lakhal (2018).

$\mathrm{H}_{2}$ : Karakteristik kepribadian mempengaruhi kualitas SIA.

\section{Struktur Organisasi Dalam Kualitas SIA}

Menurut Laudon dan Laudon (2012: 84) terdapat beberapa unsur atau karakteristik yang memiliki konsekuensi pada jenis sistem informasi yang digunakan dalam perusahaan, misalnya seperti proses bisnis, budaya organisasi, politik organisasi, lingkungan, struktur organisasi dan gaya kepemimpinan. Beberapa temuan empiris yang senada dengan pernyataan Laudon dan Laudon (2012) pernah dilakukan oleh Rahayu et al. (2014), Napitupulu (2018), Nurhayati dan
Koesdiningsih (2018) dan Nurliyani et al. (2020) terkait faktor budaya organisasi yang memiliki pengaruh dalam implementasi sistem informasi. Faktor lain yang mempengaruhi implementasi sistem informasi adalah faktor kepemimpinan (Wisna, 2016; Nurhayati dan Susanto, 2017), faktor kompetensi pengguna (Nurhayati dan Mulyani, 2015; Hertati dan Zarkasyi, 2015), faktor dukungan manajemen puncak (Chalu, 2012; Halimatusadiah et al., 2015; Susetyo et al., 2016; Murtadho et al., 2018; Darma et al., 2018; Damayanti dan Fardinal, 2019; Hertati et al., 2020b), faktor komitmen organisasi (Nurhayati, 2014; Hertati et al., 2020a; Lingga, 2021), faktor komitmen manajemen (Iskandar, 2015; Nurhayati dan Mulyani, 2015; Kuraesin et al., 2019), intention to use (Wijaya et al., 2021), faktor teknologi informasi (Kloviene dan Gimzauskiene, 2015), faktor strategi bisnis (Sari et al., 2019; Lestari dan Hertati, 2020), faktor pengendalian internal (Dalimunthe et al., 2018; Arsal dan Fardinal, 2019).

Terdapat pengaruh struktur organisasi terhadap kualitas sistem informasi akuntansi. Pernyataan tersebut ditemukan dalam penelitian yang dilakukan oleh Nusa (2015) pada 45 universitas di Kota Bandung. Kemudian Rapina et al. (2020) dalam studi empirisnya menemukan bahwa dalam struktur organisasi ada hal yang butuh dipertimbangkan yaitu tanggung jawab atas pekerjaan dari masing-masing manajer dan karyawan harus ditunjukkan dengan jelas ketika menerapkan sistem informasi akuntansi.

Struktur organisasi tergantung pada tujuan dan pendekatan manajemen serta dapat mempengaruhi penggunaan sistem informasi dimana struktur organisasi memiliki pengaruh langsung pada sistem informasi suatu organisasi (Stair dan Reynolds, 2010: 48).

Menyambung hal tersebut terdapat pernyataan bahwa sistem informasi dan struktur organisasi memiliki korelasi yang diungkapkan oleh Rachmawati (2016) dalam penelitian empirisnya pada perusahaan 
penyewaan kendaraan menemukan bahwa kualitas sistem informasinya belum maksimal dikarenakan belum jelas pemisahan fungsi akuntansi, fungsi penjualan, fungsi produksi pada aplikasi sistem informasi akuntansi manajemen yang digunakan.

Penelitian lainnya dilakukan oleh Almashaqba (2014) pada 50 orang pegawai perusahaan telekomunikasi di Jordania menemukan hubungan positif antara sistem informasi dan struktur organisasi. Hipotesis lainnya yang diuji dan memiliki hubungan positif yaitu perubahan teknologi dan perancangan struktur organisasi serta hubungan positif antara sistem informasi dan pembentukan struktur organisasi. Terdapat temuan empiris lainnya yang juga menyatakan bahwa struktur organisasi mempengaruhi bidang sistem informasi yang dilakukan oleh (Farhanghi et al., 2013; Rahayu, 2012b; Rachmawati, 2016; Rapina, 2017; Puspitawati dan Wisdayanti, 2020; Fransisca et al., 2020)

$\mathrm{H}_{3}$ : Struktur Organisasi mempengaruhi kualitas SIA.

\section{Penerapan SIA Dalam Menghasilkan Informasi Akuntansi Berkualitas}

Pembentukan informasi yang bermakna dihasilkan oleh ruang lingkup SIA serta desain fungsi dan pengeluaran yang melekat pada pertimbangan pengguna (Bodnar dan Hopwood, 2014: 3). Menurut Hall (2011: 597) kualitas SIA bertumpu secara otomatis pada gerakan daur hidup pembangunan sistem yang menghasilkan informasi akuntansi. Sistem ini memberikan informasi akuntansi kepada pengguna internal dan eksternal. Hal senada disimpulkan oleh Anggadini (2013) dalam penelitiannya pada 47 Baitulmal Wattamwil (BMT) di Jawa Barat dengan variabel independen struktur organisasi yang mempengaruhi variabel dependen penerapan sistem informasi akuntansi dan berdampak pada kualitas informasi akuntansi. Selanjutnya, Fitrios (2016) dalam studi empirisnya pada 42 rumah sakit di Provinsi Riau, Indonesia menemukan bahwa sistem informasi akuntansi akan mempengaruhi informasi akuntansi. Kualitas informasi yang dihasilkan dari SIA memberikan dampak pada keterampilan manajemen dalam menempuh aksi dan melaksanakan ketetapan sehubungan dengan operasi dari organisasi dan untuk mempersiapkan laporan keuangan yang dapat dipercaya (Hall, 2011: 134).

Dalam sistem informasi akuntansi, keberhasilan sistem informasi ditentukan dari kualitas informasi yang dihasilkannya. Sistem informasi akuntansi sebagai perantara atau alat untuk mewujudkan informasi agar para manajer proyek ataupun karyawan yang bergerak dalam tingkat organisator perusahaan bisa mengambil langkah yang tepat (Mulyani, 2015: 17). Sistem informasi akuntansi telah banyak digunakan oleh berbagai organisasi untuk mengotomatisasi dan mengintegrasikan operasi bisnis mereka operasi. Tujuan utama dari berbagai organisasi ketika mengadopsi sistem informasi adalah untuk meningkatkan efisiensi bisnis mereka dan meningkatkan daya saing (Hla dan Teru, 2015).

Bukti empiris lainnya yang dite-mukan pada penelitian Komala (2012) dan Rahayu (2012a) menyimpulkan bahwa kualitas SIA akan memproduksi kualitas informasi akuntansi sehingga ada pengaruh diantara keduanya, dan temuan empiris yang sama juga pernah dilakukan oleh (Hiyari et al., 2013); Fitriati dan Mulyani, 2015); (Rachmawati dan Fardinal, 2017); Sari, 2018a); (Meiryani et al., 2019); (Arsal dan Fardinal, 2019); (Puspitawati dan Anggadini, 2019); (Eryana dan Fardinal, 2019); (Darma dan Sagala, 2020); (Meiryani et al., 2020); (Hernanda dan Setiyawati, 2020). Selanjutnya dari penelitian Carolina (2017) yang memberi kontribusi pada perkembangan bidang ilmu sistem informasi pada perusahaan asuransi di Indonesia disimpulkan bahwa hasil penelitian memperkuat teori tentang adanya hubungan antara sistem informasi akuntansi terhadap informasi akuntansi

$\mathrm{H}_{4}$ : Kualitas SIA mempengaruhi kualitas informasi akuntansi 


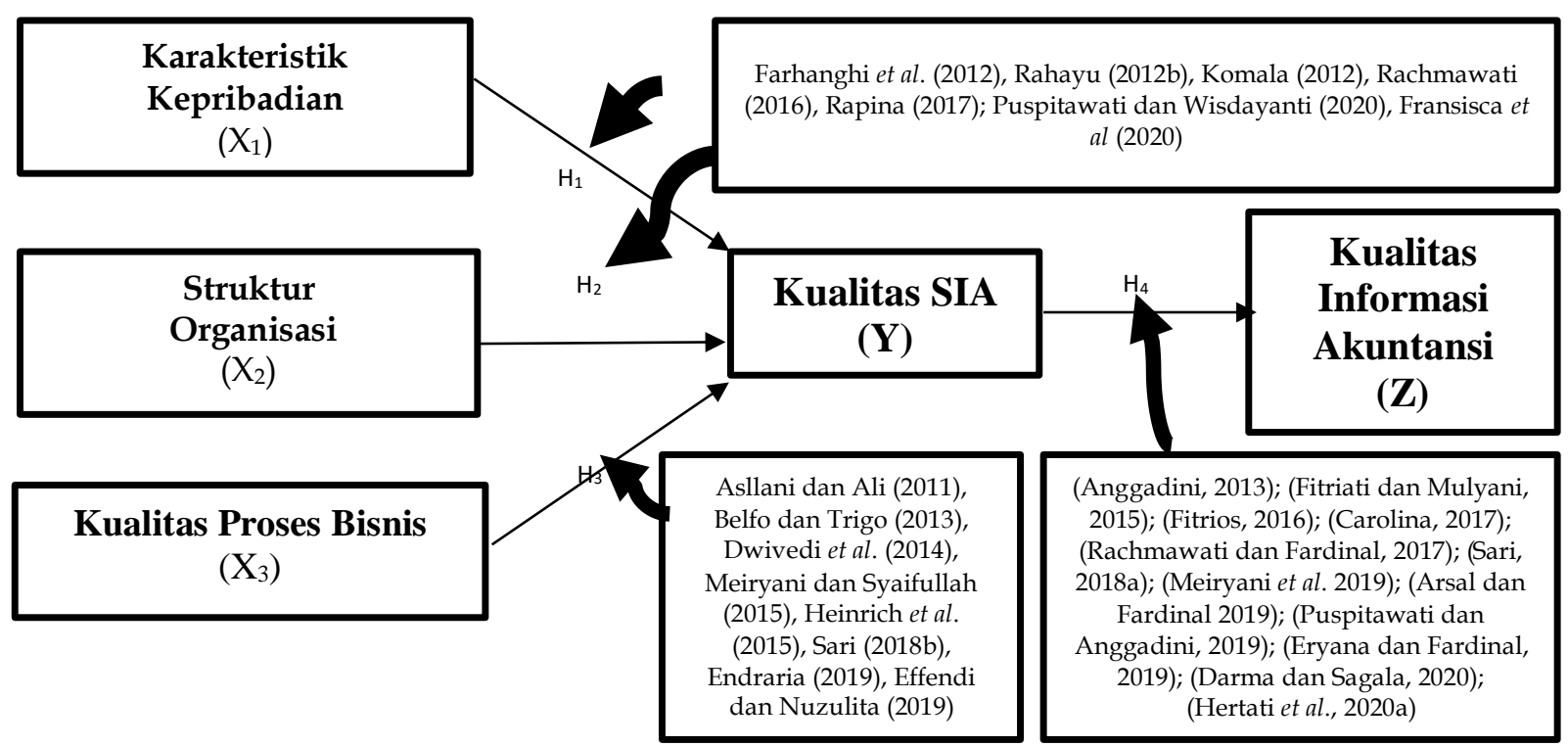

Gambar 1

Model atau Kerangka Penelitian

Sumber: Data diolah dari berbagai referensi

Berdasarkan uraian sebelumnya, dapat dibuatkan bagan kerangka pemikiran seperti pada Gambar 1.

\section{METODE PENELITIAN}

Penelitian ini merupakan explanatory research dengan menggunakan metode survey dalam mengumpulkan data. Dengan demikian, peneliti melakukan pengambilan informasi dari individu-individu selaku basis data untuk dapat menggambarkan, membandingkan dan menjelaskan bukti yang berhubungan dengan orang, keadankeadaan atau status-status tertentu (Sekaran dan Bougie, 2016: 97). Penelitian ini menggunakan organisasi perbankan sebagai unit analisis, dalam hal ini perbankan yang ada di Indonesia. Teknik pengumpulan data dalam penelitian ini menggunakan kuesioner dan sumber data yang terlibat adalah manajer operasional dan staf pada divisi akuntansi untuk menanggapi fenomena penelitian. Hal tersebut juga didasari pendapat Morley dan Parker (2015: 470) bahwa konsumen dari sistem informasi terdiri dari manajer, pegawai non manajemen dan pemakai eksternal. Target populasi pada penelitian ini adalah sebanyak 119 bank umum di Indonesia menurut daftar yang dikeluarkan oleh Otoritas Jasa Keuangan (http://www. ojk.go.id/data-alamat-kp-bank).

Peran perbankan yang sangat substantial terhadap keseimbangan dan perkembangan ekonomi (Mulyani, 2018) menjadi dasar pemilihan populasi dalam penelitian ini. Metode penetapan representative yang dipakai pada penelitian ini adalah teknik sampling probabilitas dengan teknik sampling acak. Sample acak yang didapatkan dari pengembalian kuesioner dari keseluruhan target populasi adalah 46 perusahaan perbankan di Indonesia. Model Persamaan Struktural (Structural Equation Modeling) dengan penghitungan ukuran-ukuran model dalam hal ini menggunakan metode Partial Least Square untuk menguji hipotesis penelitian. Alasan menggunakan model persamaan struktural disebabkan adanya relasi sebab akibat antar variabel dan setiap variabelnya adalah variabel yang tidak terobservasi. Adapun model pengukuran dan struktural dapat dilihat pada gambar 2: Model SEM Pengaruh Variabel-Variabel Independen Terhadap Kualitas SIA Serta Implikasinya Pada Kualitas Informasi Akuntansi. 


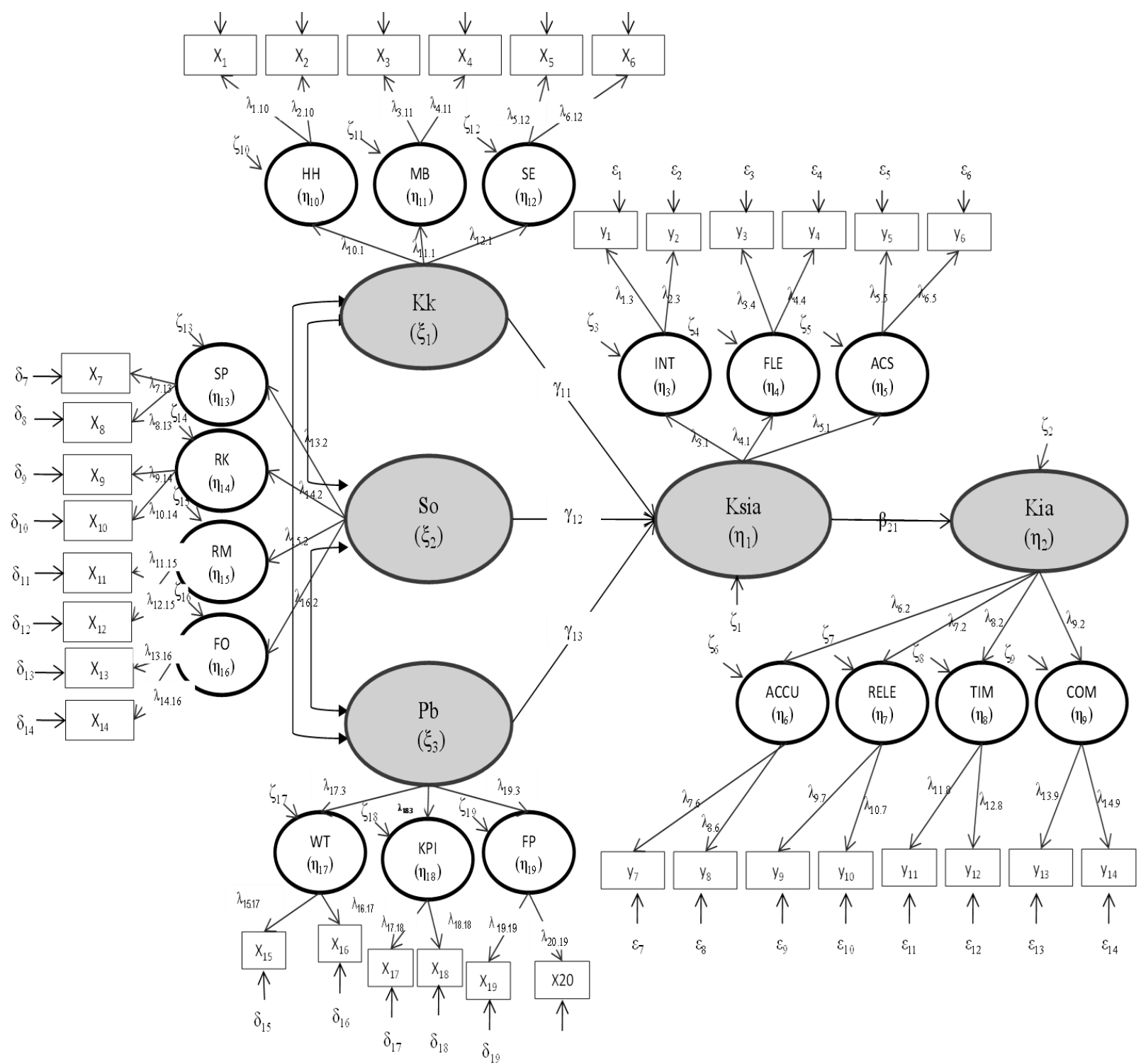

Keterangan:

$\xi_{1}=$ variabel karakteristik kepribadian

$\eta_{10}=$ dimensi sifat berhati-hati

$\eta_{11}=$ dimensi mudah bersepakat

$\eta_{12}=$ dimensi stabilitas emosi

$\xi_{1}=$ variabel struktur organisasi

$\eta_{13}=$ dimensi spesialisasi pekerjaan

$\eta_{14}=$ dimensi rantai komando

$\eta_{15}=$ dimensi rentang manajemen

$\eta_{16}=$ dimensi formalisasi

$\xi_{3}=$ variabel kualitas proses bisnis

$\eta_{17}=$ dimensi waktu

$\eta_{18}=$ dimensi kualitas proses internal

$\eta_{19}=$ dimensi fleksibilitas proses $\eta_{1}=$ variabel kualitas sistem informasi akuntansi

$\eta_{3}=$ dimensi integrasi

$\eta_{4}=$ dimensi fleksibilitas

$\eta_{5}=$ dimensi accessibility

$\eta_{2}=$ variabel kualitas informasi akuntansi

$\eta_{6}=$ dimensi akurat

$\eta_{7}=$ dimensi relevan

$\eta_{8}=$ dimensi tepat waktu

$\eta_{9}=$ dimensi lengkap

$\lambda=$ loading untuk konstruk reflektif

$\lambda=$ loading untuk variabel laten dengan dimensi

$\beta=$ koefisien jalur antar variabel endogen

$\mathrm{\gamma}=$ koefisien jalur antar variabel eksogen

$\zeta=$ kesalahan pengukuran variabel endogen

\section{Gambar 2}

\section{Model SEM Pengaruh Variabel-Variabel Independen Terhadap Kualitas SIA Serta Implikasinya Pada Kualitas Informasi Akuntansi.}

Sumber: Data olahan dengan SEM PLS 


\section{ANALISIS DAN PEMBAHASAN}

Target individu yang mengisi kuesioner dalam penelitian adalah manajer atau kepala bagian pada bagian akuntansi dan keuangan untuk kantor pusat. Untuk kantor cabang perbankan, kuesioner diisi oleh kepala bagian atau staff operasional yang terkait dengan fungsi akuntansi. Jumlah responden penelitian ini adalah 199 orang dari 46 bank umum di Indonesia.

\section{Estimasi Model PLS-SEM}

Analisis data dalam rangka menguji hipotesis penelitian menggunakan PLS-SEM model lengkapnya telah diperlihatkan pada Gambar 2.

\section{Evaluasi Model Pengukuran Reflektif Orde Kedua}

a) Validitas dimensi
Berdasarkan pengujian nilai faktor loading antara dimensi dengan konstruknya pada tabel 1 (kolom 4-8), setiap pengujian mempunyai nilai-P yang lebih kecil dari 0.05 , bila digunakan taraf signifikansi 0.05 , maka hipotesis nol yang berbunyi "loading bernilai nol" akan ditolak. Berdasarkan pendapat Bollen (1989: 199), setiap loading yang berbeda dari nol dapat disimpulkan bahwa setiap dimensi telah valid merepresentasikan konstruknya masing-masing (tabel 2, kolom 4).

b) Reliabilitas dimensi

Reliabilitas suatu dimensi akan dilihat dari nilai R2 untuk masing-masing dimensi. Bila terdapat dimensi dengan nilai R2 lebih besar dari 0.5 dianggap mempunyai reliabilitas yang baik, bila nilainya diantara 0.3 dan 0.5 reliabilitas dinyatakan kurang baik, dan bila nilainya berada di bawah 0.3 dianggap tidak reliabel (Bollen, 1989: 21).

Tabel 1

Evaluasi Model Pengukuran Reflektif Pada Tahap Kedua (Orde Kedua)-Bagian I

\begin{tabular}{|c|c|c|c|c|c|c|c|c|}
\hline \multirow[b]{2}{*}{ No } & \multirow[b]{2}{*}{ Konstruk } & \multirow[b]{2}{*}{ Dimensi } & \multicolumn{5}{|c|}{ Faktor loading } & \multirow{2}{*}{$\begin{array}{c}\mathbf{R}^{2} \\
\left(\mathbf{O}^{2}\right)\end{array}$} \\
\hline & & & $\begin{array}{c}\text { Taksiran } \\
\text { (O) }\end{array}$ & $\begin{array}{l}\text { Standar eror } \\
\text { (STDEV) }\end{array}$ & $\begin{array}{c}\text { Statistik-t } \\
(|\mathrm{O} / \mathrm{STDEV}|)\end{array}$ & Nilai-p & Signifikansi & \\
\hline$(1)$ & $(2)$ & (3) & (4) & (5) & (6) & $(7)$ & $(8)$ & $(9)$ \\
\hline 1 & KK & $\mathrm{HH}$ & 0,83 & 0,05 & 17,22 & 0,00 & signifikan & 0,69 \\
\hline 2 & & MB & 0,87 & 0,04 & 19,89 & 0,00 & signifikan & 0,75 \\
\hline 3 & & SE & 0,79 & 0,07 & 12,06 & 0,00 & signifikan & 0,63 \\
\hline 4 & KIA & $\mathrm{ACCU}$ & 0,81 & 0,04 & 18,29 & 0,00 & signifikan & 0,66 \\
\hline 5 & & $\mathrm{COM}$ & 0,87 & 0,04 & 24,31 & 0,00 & signifikan & 0,76 \\
\hline 6 & & RELE & 0,85 & 0,04 & 21,49 & 0,00 & signifikan & 0,72 \\
\hline 7 & & TIM & 0,90 & 0,02 & 39,63 & 0,00 & signifikan & 0,81 \\
\hline 8 & KPB & WT & 0,91 & 0,03 & 33,47 & 0,00 & signifikan & 0,82 \\
\hline 9 & & KPI & 0,88 & 0,03 & 28,90 & 0,00 & signifikan & 0,78 \\
\hline 10 & & FP & 0,78 & 0,07 & 11,29 & 0,00 & signifikan & 0,61 \\
\hline 11 & KSIA & ACS & 0,75 & 0,07 & 11,33 & 0,00 & signifikan & 0,57 \\
\hline 12 & & FLE & 0,93 & 0,02 & 40,98 & 0,00 & signifikan & 0,86 \\
\hline 13 & & INT & 0,91 & 0,02 & 36,48 & 0,00 & signifikan & 0,83 \\
\hline 14 & $\mathrm{SO}$ & FO & 0,93 & 0,02 & 54,79 & 0,00 & signifikan & 0,87 \\
\hline 15 & & RK & 0,87 & 0,03 & 29,17 & 0,00 & signifikan & 0,77 \\
\hline 16 & & $\mathrm{RM}$ & 0,79 & 0,08 & 10,42 & 0,00 & signifikan & 0,62 \\
\hline 17 & & SP & 0,87 & 0,04 & 21,45 & 0,00 & signifikan & 0,75 \\
\hline
\end{tabular}


Tabel 2

Lanjutan-Evaluasi Model Pengukuran Reflektif Pada Tahap Kedua (Orde Kedua)-Bagian II

\begin{tabular}{|c|c|c|c|c|c|c|c|c|}
\hline \multirow{2}{*}{ No } & \multirow{2}{*}{ Konstruk } & \multirow{2}{*}{ Dimensi } & \multicolumn{2}{|c|}{ Dimensi } & \multirow{2}{*}{ AVE } & \multirow{2}{*}{ CR } & \multicolumn{2}{|c|}{ Konstruk } \\
\hline & & & Validitas & Reliabilitas & & & Validitas & Reliabilitas \\
\hline (1) & (2) & (3) & (4) & (5) & (6) & (7) & $(8)$ & $(9)$ \\
\hline 1 & KK & $\mathrm{HH}$ & Valid & reliabel & 0,52 & 0,86 & valid & reliabel \\
\hline 2 & & MB & Valid & reliabel & & & & \\
\hline 3 & & SE & Valid & reliabel & & & & \\
\hline 4 & KIA & ACCU & Valid & reliabel & 0,61 & 0,93 & valid & reliabel \\
\hline 5 & & $\mathrm{COM}$ & Valid & reliabel & & & & \\
\hline 6 & & RELE & Valid & reliabel & & & & \\
\hline 7 & & TIM & valid & reliabel & & & & \\
\hline 8 & KРB & WT & valid & reliabel & 0,59 & 0,89 & valid & reliabel \\
\hline 9 & & KPI & valid & reliabel & & & & \\
\hline 10 & & FP & valid & reliabel & & & & \\
\hline 11 & KSIA & ACS & valid & reliabel & 0,60 & 0,90 & valid & reliabel \\
\hline 12 & & FLE & valid & reliabel & & & & \\
\hline 13 & & INT & valid & reliabel & & & & \\
\hline 14 & SO & FO & valid & reliabel & 0,65 & 0,94 & valid & reliabel \\
\hline 15 & & RK & valid & reliabel & & & & \\
\hline 16 & & $\mathrm{RM}$ & valid & reliabel & & & & \\
\hline 17 & & SP & valid & reliabel & & & & \\
\hline
\end{tabular}

Sumber: data olahan

Tabel 3

Evaluasi Model Struktural

\begin{tabular}{|c|c|c|c|c|c|c|c|c|c|c|c|}
\hline \multirow[b]{2}{*}{$\begin{array}{l}\mathbf{N} \\
\mathbf{0}\end{array}$} & \multicolumn{3}{|c|}{ Variabel } & \multicolumn{5}{|c|}{ Koefisien pengaruh } & \multirow[b]{2}{*}{$\begin{array}{l}\text { VI } \\
\text { F }\end{array}$} & \multirow[b]{2}{*}{$\begin{array}{l}\text { Kolini } \\
\text { e-ritas }\end{array}$} & \multirow[b]{2}{*}{$\mathbf{R} 2$} \\
\hline & $\begin{array}{c}\text { Penyeb } \\
\text { ab }\end{array}$ & $\begin{array}{c}\text { Akib } \\
\text { at }\end{array}$ & $\begin{array}{c}\text { Peranta } \\
\text { ra }\end{array}$ & $\begin{array}{l}\text { Taksir } \\
\text { an }(\mathrm{O})\end{array}$ & $\begin{array}{c}\text { Standa } \\
\text { r eror } \\
\text { (STDE } \\
\text { V) }\end{array}$ & $\begin{array}{c}\text { Statistik-t } \\
\text { (|O/STDE } \\
\text { V |) }\end{array}$ & $\begin{array}{c}\text { Nil } \\
\text { ai } \\
\text { p }\end{array}$ & $\begin{array}{c}\text { Signifika } \\
\text { nsi }\end{array}$ & & & \\
\hline (1 & (2) & (3) & $(4)$ & (5) & (6) & $(7)$ & $(8)$ & (9) & $\begin{array}{c}(10 \\
)\end{array}$ & (11) & \\
\hline 1 & KK & KSIA & & 0,02 & 0,17 & 0,13 & 0,89 & non-sig. & $\begin{array}{c}1,4 \\
9 \\
2,0\end{array}$ & $\begin{array}{l}\text { non- } \\
\text { kol. } \\
\text { non- }\end{array}$ & $\begin{array}{c}0,5 \\
9\end{array}$ \\
\hline 2 & KPB & KSIA & & 0,39 & 0,22 & 1,77 & 0,08 & signifikan & $\begin{array}{c}7 \\
2,1\end{array}$ & $\begin{array}{l}\text { kol. } \\
\text { non- }\end{array}$ & \\
\hline 3 & SO & KSIA & & 0,44 & 0,29 & 1,50 & 0,13 & non-sig. & $\begin{array}{c}3 \\
1,0\end{array}$ & $\begin{array}{l}\text { kol. } \\
\text { non- }\end{array}$ & 0,6 \\
\hline 4 & KSIA & KIA & & 0,78 & 0,06 & 12,63 & 0,00 & signifikan & 0 & kol. & 0 \\
\hline 5 & KI & KIA & KSIA & 0,02 & 0,14 & 0,13 & 0,90 & non-sig. & & & \\
\hline 6 & KPB & KIA & KSIA & 0,30 & 0,18 & 1,62 & 0,10 & signifikan. & & & \\
\hline 7 & $\mathrm{SO}$ & KIA & KSIA & 0,34 & 0,23 & 1,49 & 0,14 & non-sig. & & & \\
\hline
\end{tabular}

Sumber: data olahan 
Dari Tabel 1 - kolom (9) dapat terlihat bahwa semua dimensi dalam penelitian ini mempunyai nilai $\mathrm{R} 2$ di atas 0.5 yang berarti setiap dimensi mempunyai tingkat reliabili-tas yang baik (tabel 2, kolom 5)

c) Validitas konvergensi dimensi untuk tiap konstruk

Batasan dimensi-dimensi suatu konstruk mempunyai validitas konvergensi yang baik bila memiliki nilai AVE lebih dari 0.5 (Hair et al., 2014: 103). Dari Tabel 2 (kolom 6) kita ketahui bahwa pada umunya dimensidimensi pada penelitian ini memiliki nilai AVE di atas 0.5. Maka dapat dikatakan bahwa dimensi-dimensi setiap konstruk mempunyai tingkat validitas konvergensi yang baik.

d) Reliabilitas konsistensi internal dimensi untuk tiap konstruk

Batasan suatu dimensi-dimensi suatu konstruk dikatakan mempunyai konsistensi internal yang baik bila memiliki nilai CR lebih besar dari 0.7 (Hair et al., 2014: 101). Bila kita melihat tabel 2, kolom 7, maka semua CR dalam penelitian ini bernilai lebih besar dari 0.7 dan ini berarti bahwa dimensi-dimensi setiap konstruk mempunyai konsistensi internal yang baik. Hal yang tidak kalah penting yaitu bahwa nilai CR yang lebih besar dari 0.9 kemungkinan akan berdampak pada hasil penaksiran parameter untuk model struktural (under estimate).

\section{Evaluasi Model Struktural}

Evaluasi model struktural menyangkut pada pengujian signifikansi koefisien-koefisien pengaruh antar konstruk yang dihipotesiskan, tetapi sebelumnya harus dievaluasi dahulu mengenai permasalahan kolinearitas antar variabel eksogen meliputi variabel karakteristik kepribadian, struktur organisasi dan kualitas proses bisnis. Sebelum melakukan evaluasi antar konstruk, yang terkait pada pengujian hipotesis yang tergambar pada model struktural, terlebih dahulu perlu dilakukan evaluasi apakah terdapat masalah kolinearitas antar variabel independen yaitu karakteristik kepribadian, struktur organisasi dan kualitas proses bisnis. Berdasarkan hasil pengolahan data yang disajikan pada tabel 3 kolom 10 dan 11, dapat diketahui bahwa variabel-variabel tersebut memiliki VIF lebih kecil dari 5 . Dengan demikian tidak terdapat masalah kolinearitas antar variabel independen tersebut.

Evaluasi terhadap signifikansi dari koefisien-koefisien pengaruh antar variabel terkait pada pengujian hipotesis penelitian sebagai berikut:

\section{Karakteristik Kepribadian mempengaruhi Kualitas SIA}

i) Hipotesis Penelitian

Uji hipotesis statistik yang digunakan adalah sebagai berikut :

$\mathrm{H}_{0}: \gamma_{11}=0$ : Karakteristik kepribadian tidak mempengaruhi kualitas SIA

$\mathrm{H}_{1}: \gamma_{11} \neq 0$ :Karakteristik kepribadian mempengaruhi kualitas SIA

ii) Statistik Uji Yang Digunakan

$$
t=\frac{\hat{\gamma}_{11}}{\operatorname{Se}\left(\hat{\gamma}_{11}\right)}
$$

iii) Kriteria Uji Yang Digunakan

Tolak $\mathrm{H}_{0}$ jika $\mathrm{p}$ value lebih kecil dari taraf signifikansi $=0.10$

iv) Kesimpulan

Nilai $p$ value $=0.89$ dapat dilihat pada tabel 3 kolom 8, ternyata lebih besar dari 0.10, yang berarti bahwa hipotesis nol tidak berhasil ditolak. Dapat disimpulkan bahwa karakteristik kepribadian tidak mempengaruhi kualitas SIA.

\section{Struktur Organisasi mempengaruhi Kualitas SIA}

i) Hipotesis Penelitian

$\mathrm{H}_{0}: \gamma_{12}=0$ : Struktur Organisasi tidak mempengaruhi kualitas SIA

$\mathrm{H}_{1}: \gamma_{12} \neq 0$ : Struktur Organisasi mempengaruhi kualitas SIA

ii) Statistik Uji Yang Digunakan 


$$
t=\frac{\widehat{\gamma}_{12}}{\operatorname{Se}\left(\widehat{\gamma}_{12}\right)}
$$

iii) Kriteria Uji Yang Digunakan

Tolak $\mathrm{H}_{0}$ jika $\mathrm{p}$ value lebih kecil dari taraf signifikansi $=0.10$

iv)Kesimpulan

Nilai $\mathrm{p}$ value $=0.13$ dapat dilihat pada tabel 3 kolom 8, ternyata lebih besar dari 0.10 , yang berarti bahwa hipotesis nol tidak berhasil ditolak. Dapat disimpulkan bahwa struktur organisasi tidak mempengaruhi kualitas sistem informasi akuntansi.

\section{Kualitas Proses Bisnis mempengaruhi Kualitas SIA}

i) Hipotesis Penelitian

Uji hipotesis statistik yang digunakan adalah sebagai berikut:

$\mathrm{H}_{0}: \gamma_{13}=0$ :Kualitas Proses Bisnis tidak mempengaruhi kualitas SIA

$\mathrm{H}_{1}: \gamma_{13} \neq 0$ :Kualitas Proses Bisnis mempengaruhi kualitas SIA

ii)Statistik Uji Yang Digunakan adalah

$$
t=\frac{\widehat{\gamma}_{13}}{\operatorname{Se}\left(\widehat{\gamma}_{13}\right)}
$$

ii) Kriteria Uji

Tolak $\mathrm{H}_{0}$ jika $\mathrm{p}$ value lebih kecil dari taraf signifikansi $=0.10$

iv)Kesimpulan

Nilai $\mathrm{p}$ value $=0,08$ dapat dilihat pada tabel 3 kolom 8 , ternyata lebih kecil dari 0.10 , yang berarti bahwa hipotesis nol berhasil ditolak. Dapat disimpulkan kualitas proses bisnis mempengaruhi kualitas SIA dengan kuat pengaruh sebesar 0,39. Artinya untuk setiap kenaikan 1 standar deviasi skor kualitas proses bisnis maka menyebabkan terdapat kenaikan pada skor kualitas sistem informasi akuntansi rata-rata sebesar 0,39 standar deviasi dengan menganggap variabel lainnya konstan. Dengan kata lain berarti semakin berkualitas proses bisnis maka semakin berkualitas sistem informasi akuntansi.
Kualitas SIA mempengaruhi Kualitas Informasi Akuntansi

i) Hipotesis Penelitian

Uji hipotesis statistik yang digunakan adalah sebagai berikut :

$$
\begin{aligned}
& \mathrm{H}_{0}: \beta 21=0 \quad \begin{array}{l}
: \text { Kualitas Proses Bisnis tidak } \\
\text { mempengaruhi kualitas SIA }
\end{array} \\
& \begin{aligned}
& \mathrm{H}_{1}: \beta_{21} \neq 0 \quad: \text { Kualitas Proses Bisnis } \\
& \text { mempengaruhi kualitas SIA }
\end{aligned} \\
& \text { Statistik } \text { Uji Yang Digunakan }
\end{aligned}
$$

$$
t=\frac{\hat{\beta}_{21}}{\operatorname{Se}\left(\widehat{\beta}_{21}\right)}
$$

ii) Kriteria Uji Yang Digunakan

Tolak H0 jika p value lebih kecil dari taraf signifikansi $=0,10$

\section{iv)Kesimpulan}

Nilai $p$ value $=0,00$ dapat dilihat pada tabel 3 kolom 8 , ternyata lebih kecil dari 0.10 , yang berarti bahwa hipotesis nol berhasil ditolak. Kesimpulannya adalah bahwa kualitas SIA mempengaruhi kualitas informasi akuntansi dengan kuat pengaruh sebesar 0.78. Artinya untuk setiap kenaikan 1 standar deviasi skor kualitas sistem informasi akuntansi maka menyebabkan terdapat kenaikan pada skor kualitas informasi akuntansi rata-rata sebesar 0,78 standar deviasi dengan menganggap variabel lainnya konstan. Dengan kata lain berarti semakin berkualitas sistem informasi akuntansi maka semakin berkualitas informasi akuntansi

\section{Pembahasan \\ Karakteristik Kepribadian Mempengaruhi Kualitas SIA}

Aplikasi SIA perusahaan perbankan belum seutuhnya mengakomodir tanggung jawab pemeriksaan kembali atas semua aspek pekerjaan. Hal ini terjadi karena pemeriksaan kembali hanya dilakukan oleh seorang petugas yang bertanggungjawab untuk memeriksa hasil input dari bagian lain. Misalnya pada saat nasabah membuka rekening baru melalui customer service atau mentransfer sejumlah dana melalui teller, 
hasil kerja mereka akan mendapat persetujuan oleh seorang supervisor saja. Tingkat yang lebih tinggi posisinya dari supervisor seperti misalnya kepala cabang, tidak akan ikut memberi persetujuan atas aktivitas yang dilakukan oleh customer service atau teller tadi. Padahal mereka semua berada dalam posisi yang sama fungsinya sebagai pengguna sistem informasi akuntansi.

Selanjutnya diketahui juga bahwa sistem informasi akuntansi yang diterapkan belum sepenuhnya mengakomodir keinginan yang kuat dan secara tekun untuk mempelajari sistem informasi akuntansi. Pada bagian yang melayani nasabah langsung yaitu customer service dan teller seharusnya memiliki keinginan yang kuat dan tekun mempelajari aplikasi sistem informasi akuntansi yang digunakan. Pada bagian lain misalnya bagian consumer card ternyata sistem informasi akuntansi yang diterapkan pada mayoritas bank umum sering mengalami pembaharuan yang membuat pengguna harus terus beradaptasi. Hal ini sering membuat pengguna merasa jenuh untuk mempelajarinya karena pembaharuan tersebut membuat proses penyelesaian pekerjaan jadi terhambat.

Berdasarkan uraian di atas, dapat dikatakan bahwa semakin sistem informasi akuntansi yang diterapkan mampu mengakomodir karakteristik kepribadian maka akan meningkatkan kualitas sistem informasi akuntansi. Hal ini sejalan dengan pernyataan bahwa interaksi dari berbagai ciri kepribadian yang ditemukan pada penelitian Lea et al., (2019) akan bermanfaat secara individual pada saat penerapan sistem yang disupport secara terkomputerisasi dan memiliki pengaruh pada kinerja pembelajaran ERP. Menyambung pendapat tersebut maka Taherdoost dan Keshavarzsaleh (2015) menemukan adanya hubungan antara tingkat implementasi penggunaan sistem yang dibuat harus sesuai dengan kebutuhan dari pengguna. Kegagalan ssitem sering terjadi karena sikap, kepuasan, dan frekuensi penggunaannya tidak sesuai dengan tingkat penggunaan sistem.

\section{Struktur Organisasi Mempengaruhi Kualitas SIA}

Sistem informasi akuntansi belum maksimal dalam menyerap spesialisasi pekerjaan pada struktur organisasi. Aplikasi sistem informasi akuntansi memang telah mengadopsi tahapan yang dipecah menjadi sejumlah daftar tugas yang dibutuhkan. Mayoritas bank umum telah jelas dalam pemisahan tugas yang dikerjakan oleh satu bagian dengan bagian lain, seperti misalnya tugas seorang customer service dan teller pasti akan berbeda dan mereka tidak bisa saling bertukar pekerjaan yang telah ditetapkan. Antara ruangan customer service dan teller memiliki dinding pemisah, begitu juga dengan aplikasi yang dijalankan memiliki paswordnya masing-masing baik sebagai teller atau sebagai customer service.

Selanjutnya diketahui bahwa aplikasi sistem informasi akuntansi belum mengakomodir tugas-tugas karyawan yang relevan dengan spesialisasi mereka, karena aplikasi yang digunakan untuk kantor cabang, divisi retail risk, divisi komersial dan divisi consumer card pada sebagian besar bank umum masih berlainan aplikasinya. Hal ini menyebabkan sistem informasi akuntansi belum berjalan dengan otomatis mengirimkan data-data yang dibutuhkan pada saat membuat laporan. Ada beberapa laporan yang harus dikerjakan manual dengan cara menggabungkan data dari aplikasi sistem informasi akuntansi yang berlainan dari satu divisi ke divisi lainnya.

Menyambung hal tersebut ditemu-kan bahwa aplikasi sistem informasi akun-tansi belum sepenuhnya dalam menyerap kesatuan komando. Mayoritas bank umum belum memenuhi kesatuan perintah yang mensyaratkan idealnya seseorang hanya mempunyai seorang atasan. Misalnya atasan seorang kepala cabang bank di Bandung adalah kepala regional Kantor Pusat Bandung. Sempat terjadi ketika kepala cabang menerima laporan pembukuan setiap 
hari dari bagian pembukuan yang berada di regional kantor pusat Bandung melalui email terlihat perhitungan yang janggal. Kepala cabang dapat langsung menyampaikan hal tersebut pada bagian pembukuan tanpa harus melapor terlebih dahulu pada atasannya yaitu kepala regional Kantor Pusat Bandung. Bagian pembukuan karena takut ditegur kepala regional Kantor Pusat Bandung, segera merevisi laporan tersebut, namun tidak menginformasikan kembali hasil revisian pada kepala cabang tersebut, namun menginformasikan pada bawahan dari kepala cabang yang dimaksud.

Beberapa responden yang diwawancarai juga menyatakan bahwa aplikasi sistem informasi akuntansi belum optimal dalam mengakomodir jumlah atasan dan bawahan dalam organisasi. Untuk bank umum ini mempunyai bagian analis kredit yang secara ideal hanya dikerjakan oleh seorang petugas saja tanpa atasan dan bawahan, karena analis kredit ini hanya menyelesaikan penugasan yang tercermin dalam inbox pada aplikasi sistem informasi akuntansinya. Pada kenyataannya analis kredit ini malah ada yang membawahi bagian loan factory dan terdiri dari beberapa orang individu. Hal ini tidak tercermin dalam aplikasi sistem informasi bahwa bagian loan factory berada di bawah tingkatan analis kredit.

Berdasarkan uraian di atas, dapat dikatakan bahwa semakin sistem informasi akuntansi yang diterapkan mampu mengakomodir struktur organisasi maka akan meningkatkan kualitas sistem informasi akuntansi. Hal ini sejalan dengan pernyataan dari Carolina (2014) dalam studi empirisnya pada 32 perusahaan manufaktur di Bandung menyimpulkan bahwa budaya organisasi, komitmen organisasi dan struktur organisasi mempengaruhi kualitas sistem informasi akuntansi. Hal senada dengan Carolina (2014) adalah studi empiris yang dilakukan oleh Almashaqba (2014) pada 50 orang pegawai perusahaan telekomunikasi di Jordania menemukan hubungan positif antara sistem informasi dan struktur organisasi. Teori yang dikemukakan oleh O'Brien dan Marakas (2011: 16-17) menunjukkan bahwa sistem informasi dan teknologi harus dikelola dengan baik untuk mendukung strategi bisnis, proses bisnis, struktur organisasi dan budaya organisasi.

\section{Kualitas Proses Bisnis Mempengaruhi Kualitas SIA}

Aplikasi SIA mencerminkan waktu pemrosesan secara optimal. Hal ini dikarenakan adanya keterlambatan penarikan data dari aplikasi SIA karena mereka berebut dengan giliran dari kawasan Indonesia Tengah dan kawasan Indonesia Timur. Banyaknya data yang diambil, akan memerlukan waktu pemrosesan yang semakin lama. Aktivitas lain, seperti: transfer dana dari kantor cabang telah diakomodir waktu pemrosesannya oleh aplikasi sistem informasi akuntansi. Ada dua pilihan transfer yaitu LLG (Lalu Lintas Giro) dan RTGS (Real Time Gross Settlement) dan dua macam transfer tersebut akan sampai pada bank tujuan di hari yang sama, meskipun biaya transfer yang dibebankan berbeda.

Untuk waktu tunggu pada sebagian bank umum juga berbeda-beda tergantung dari kebijakan masing-masing. Sebagai contoh adalah aplikasi sistem informasi akuntansi untuk pembukaan rekening nasabah yang baru maka waktu tunggu yang dibutuhkan ada yang hanya 5 menit hingga 20 menit. Hal ini tergantung bagaimana aplikasi sistem informasi akuntansi mengakomodir data nasabah yang diinput ketika terdapat pertanyaan konfirmasi pada nasabah dari yang sederhana hingga yang kompleks. Pertanyaan kompleks tersebut misalnya adalah tentang FATCA (Foreign Account Tax Compliance Act) yaitu suatu ketetapan baru yang dimunculkan untuk mendukung dalam memberantas penyelewengan pajak (tax evasion) di Amerika Serikat). Contoh lain adalah untuk pin dan kartu ATM nasabah yang baru membuka rekening, ada bank yang aplikasi sistem informasi akuntansinya langsung mengirimkan pin perdana pada handphone nasabah, namun ada juga bank yang tidak memiliki 
fasilitas tersebut pada aplikasi sistemnya sehingga meminta nasabah secara manual mengambilnya di lokasi antrian teller.

Dari beberapa pernyataan responden yang diwawancarai diketahui SIA yang digunakan saat ini tidak sepenuhnya dipersiapkan untuk menghadapi berbagai situasi dan kondisi yang berfluktuasi dalam menanggapi penyesuaian dan perbaikan. Misalnya ketika seorang manager pada bagian kartu kredit akan menyetujui suatu transaksi yang ternyata secara perhitungan harus dinaikkan deviasinya namun tidak tersedia menunya di aplikasi sistem informasi akuntansinya, maka manager tersebut umumnya melakukan konfirmasi pada senior manager diatasanya dan diperintahkan untuk menginput catatan pada aplikasi sistem informasinya bahwa transaksi tersebut telah dinaikkan deviasinya. Berdsasarkan uraian di atas, dapat dikatakan bahwa semakin sistem informasi akuntansi yang diterapkan mampu mengakomodir proses bisnis maka akan meningkatkan kualitas sistem informasi akuntansi. Terdapat beberapa unsur atau karakteristik yang memiliki konsekuensi pada jenis sistem informasi yang digunakan dalam perusahaan, misalnya seperti proses bisnis, budaya organisasi, politik organisasi, lingkungan, struktur organisasi dan gaya kepemimpinan (Laudon dan Laudon, 2012: 84).

\section{Kualitas SIA Mempengaruhi Kualitas Informasi Akuntansi}

Aplikasi Sistem informasi akuntansi belum maksimal mempersiapkan beberapa aplikasi yang memiliki keterkaitan fungsi masing-masing karena masih terdapat masalah pada bank umum belum mampu memperoleh informasi dari bidang fungsional yang berbeda-beda. Misalnya pada bagian kartu kredit dan loan masih belum terintegrasi, karena bila ada seorang nasabah memiliki kredit komersial milyaran rupiah, kemudian bila nasabah tadi ingin memiliki kartu kredit, maka harus tetap melakukan aplikasi seperti nasabah baru karena nasabah tadi belum dapat dilihat identitasnya pada segmen kartu kredit. Dengan kata lain, aplikasi sistem informasi akuntansi yang digunakan dalam perbankan saat ini belum terintegrasi secara harmonis dengan bagian lain.

Selama ini software sistem informasi akuntansi yang digunakan telah menunjukkan adanya integrasi yang harmonis antara perangkat komputer, software, peralatan komunikasi, prosedur pengoperasian, data yang dimasukkan, tugas yang harus dijalankan serta menghasilkan informasi akuntansi apa adanya sesuai dengan kebutuhan informasi. Misalnya seorang kepala cabang dapat langsung mengetahui jumlah nasabah dan dana nasabah setiap saat pada aplikasi sistem informasi akuntansi yang digunakannya. Terdapat koneksi antara menu aplikasi yang digunakan di bagian teller dan bagian customer service, sehingga seorang kepala cabang dapat melihat aktivitas yang sedang dikerjakan oleh mereka pada aplikasi sistem informasi akuntansinya.

Aplikasi sistem informasi akuntansi yang digunakan belum optimal dalam menunjukkan informasi akuntansi yang sesuai dengan kebutuhan. Hal ini terjadi karena selama ini software sistem informasi akuntansi yang digunakan baik sebagai manajer, supervisor dan karyawan non manajer serta pemilik, investor dan pemegang saham belum sepenuhnya berguna dalam menghasilkan informasi akuntansi yang sesuai dengan kebutuhan. Misalnya seorang kepala cabang setiap harinya telah menerima laporan pada aplikasi sistem informasi akuntansinya tentang berapa profit cabang saat itu, jumlah dana nasabah yang terhimpun dan jumlah kredit yang telah disalurkan. Seorang kepala cabang berhak mengevaluasi permohonan kredit yang diberikan di area kantor cabangnya, namun keputusan yang harus diambil tidak dapat dilihat pada aplikasi sistem informasi akuntansinya, meskipun laporan mengenai jumlah kredit yang disalurkan, diterima setiap hari. 
Perangkat lunak sistem informasi belum digunakan secara maksimal untuk dapat diakses dan dioperasikan kapan saja dan dimana saja. Beberapa perbankan belum memiliki software sistem informasi akuntansi yang dapat diakses dimana saja dan kapan saja. Sehingga untuk dapat mengakses harus selalu berada di tempat bekerja atau di dalam perbankan. Maka dapat dikatakan bahwa sistem informasi akuntansi belum optimal mengakomodir accesibility.

Sistem informasi akuntansi akan menghasilkan informasi akuntansi (Puspitawati dan Anggadini, 2019; Eryana dan Fardinal, 2019; Darma dan Sagala, 2020). Produksi informasi yang berkualitas dibatasi oleh lingkungan sistem informasi akuntansi yang baik yang akan melekat dalam keputusan user (Bodnar dan Hopwood, 2014: 3). Pada umumnya sistem informasi akuntansi digunakan sebagai alat untuk menganalisis keputusan atau sebagai dasar pembuatan keputusan yang terkait dengan transaksi perusahaan (Mulyani, 2015: 24)

\section{SIMPULAN DAN SARAN \\ Simpulan}

Hasil penelitian ini menunjukkan bahwa di Era Revolusi Industri 4.0 saat ini, kualitas sistem informasi akuntansi di industri perbankan tetap mempengaruhi kualitas informasi akuntansinya. Hal ini dapat terlihat ketika sistem informasi akuntansi perbankan Indonesia yang telah meliputi aspek integrasi, fleksibilitas dan accessibility ini telah terakomodir dengan baik dalam aplikasinya namun masih terdapat integrasi antara komponen dengan subsistem yang belum harmonis dari satu segmen ke segmen yang lainnya, maka hal ini menyebabkan sistem informasi akuntansi mereka belum mampu mencerminkan profil konsumennya dengan baik.

Hasil penelitian ini juga menunjukkan bahwa faktor penting yang menjadi perhatian perbankan di Indonesia dalam membangun sistem informasi akuntansinya adalah kualitas proses bisnis. Beberapa dimensi terkait kualitas proses bisnis yang meliputi dimensi waktu, kualitas proses internal dan fleksibilitas proses telah diakomodir dalam aplikasi sistem informasi akuntansi mereka, walaupun dari sisi dimensi waktu dalam proses bisnis mereka masih perlu memperoleh perhatian lebih lanjut agar dapat terakomodir oleh aplikasi sistem informasi akuntansinya dengan lebih baik, khususnya saat mereka hendak melakukan penarikan data dalam skala besar secara bersamaan dari beberapa kantor cabang.

Selanjutnya hasil penelitian ini juga menunjukkan bahwa di dalam proses pengembangan sistem informasi akuntansi, karakteristik kepribadian belum menjadi faktor penentu keberhasilan sistem informasinya. Selain itu, keberadaan pedoman tugas dan wewenang masing-masing karyawan yang merupakan bagian dari pengembangan struktur organisasinya, juga masih belum disahkan oleh pihak yang berwenang dan masih terdapat tumpang tindih ataupun penumpukan pekerjaan di unit-unit tertentu. Kondisi ini menyebabkan hal-hal yang berkaitan dengan karakteristik kepribadian dan struktur organisasi tersebut belum terakomodir secara optimal oleh aplikasi sistem informasi akuntansi di perbankan, sehingga baik karakteristik kepribadian maupun keberadaan struktur organisasi dalam industri perbankan di Indonesia masih belum menunjukkan pengaruhnya terhadap kualitas sistem informasi akuntansi di industri perbankan Indonesia.

\section{Saran}

Berdasarkan hasil penelitian ini, perusahaan perbankan di Indonesia sebaiknya dapat mempertimbangkan faktor karakteristik kepribadian sebagai salah satu faktor penentu keberhasilan penerapan sistem informasi akuntansinya. Dalam hal ini, mereka perlu melaksanakan proses seleksi karyawan berdasarkan kepribadian calon karyawan tersebut sehingga perusahaan dapat memperoleh sumber daya manusia dengan karakteristik kepribadian yang mampu memberikan kontribusi positif ter- 
hadap keberhasilan penerapan sistem informasi akuntansi di tempat mereka bekerja.

Selain itu, dalam pengembangan struktur organisasinya, bank sebaiknya turut mempertimbangkan pembagian tugas dan wewenang masing-masing karyawan secara jelas dan konsisten, khususnya bagi karyawan yang bertugas atau memiliki wewenang dalam penggunaan sistem informasi akuntansi. Pembagian tugas dan wewenang ini perlu didokumentasikan dan disahkan oleh pihak yang berwenang. Selanjutnya dokumen pembagian tugas dan wewenang yang telah disahkan ini, dapat menjadi pedoman bagi masing-masing karyawan dalam menjalankan peran mereka di tempat mereka bekerja sehingga mereka dapat bekerja secara sinergis dengan rantai komando yang lebih jelas sesuai dengan tugas dan wewenangnya untuk mendukung keberhasilan penerapan sistem informasi akuntansi dalam menghasilkan informasi yang berkualitas.

Sehubungan dengan pengembangan kualitas proses bisnis di dunia perbankan Indonesia, pihak bank perlu meningkatkan fleksibilitas dari aplikasi/perangkat lunak secara berkesinambungan agar dapat selalu mengakomodir kebutuhan informasi yang berkembang sejalan dengan kompleksitas persaingan di kalangan industri perbankan tanpa mengalami kendala dari sisi waktu, khususnya saat penarikan data dalam skala besar secara bersamaan. Dalam hal ini, akan lebih baik jika fitur dalam sistem informasi akuntansi mereka dapat disajikan dan dioperasikan secara sederhana sehingga mudah untuk dipelajari dan mendukung pola kerja lebih cepat, efisien dan efektif dalam menghasilkan informasi akuntansi yang berkualitas.

Pada akhirnya, demi meningkatkan kualitas informasi akuntansi serta manfaatnya bagi para pengguna, maka selain mengembangkan perangkat lunak secara berkesinambungan, bank sebaiknya juga dapat meningkatkan fasilitas perangkat keras, prosedur, database dan jaringan teknologi komunikasi yang terintegrasi, stabil dan berkualitas. Dengan demikian, diharapkan proses penginputan data serta proses penarikan data dan informasi dapat dilakukan secara fleksibel baik dari sisi waktu dan tempat tanpa mengorbankan sisi pengendalian internalnya.

\section{DAFTAR PUSTAKA}

Almashaqba, Z. M. S. 2014. The Impact of Management Information Systems (MIS) on the Characteristics of the Organizational Structure in the Organization (a Study in the Communications Company North Province/Jordan). Interdisciplinary Journal of Contemporary Research in Business 6(2): 126-146.

Anggadini, S. D. 2013. The Accounting Information Quality and the Accounting Information System Quality through the Organizational Structure: a Survey of the Baitulmal Wattamwil (BMT) in West Java Indonesia. International Journal of Business and Management Invention 2(10): 12-17.

Arsal, R. dan Fardinal. 2019. The Effect of Competence of Human Resources and the Effectiveness of Internal Audits on the Implementation of Accounting Information Systems and Its Implications on the Quality of Financial Reports. EPRA International Journal of Research and Development 4(4): 360-371.

Asllani, A. dan A. Ali. 2011. Addressing Vulnerability of Mobile Computing: a Managerial Perspective. International Journal of Computer Science and Information Security 9(3): 1-5.

Barnet, T., A. W. Pearson, R. Pearson, dan F. W. Kellermanns. 2015. Five-Factor Model Personality Traits as Predictors of Perceived and Actual Usage of Technology. European Journal of Information Systems 24(4): 374-390. https://doi. org/ 10.1057/ejis.2014.10

Belfo, F. dan A. Trigo. 2013. Accounting Information Systems: Tradition and Future Directions. Procedia Technology 9: 536-546. DOI:10.16/j.protcy.2013.12.060 
Bodnar, G. H. dan W. S. Hopwood. 2014. Accounting Information Systems. Tenth Edition. Pearson Education, Inc. USA.

Bollen, K. A. 1989. Structural Equations with Latent Variables. John Wiley \& Sons Inc. Canada.

Carolina, Y. 2014. Organizational Factors and Accounting Information System Quality (Empiric Evidence From Manufacturing Firms in Bandung Indonesia). Research Journal of Finance and Accounting 5(5): 192-199.

Carolina, Y. 2017. Understanding AIS User Knowledge, AIS Quality, and Accounting Information Quality. Accounting $\mathcal{E}$ Finance Review (AFR) 2(3): 32-37.

Chalu, H. 2012. Analysis of Stakeholder Factors Influencing the Effectiveness of Accounting Information Systems in Tanzania's Local Authorities. Business Management Review 16(1): 1-32.

Dalimunthe, A. R., I. H. Napitupulu, dan A. Situngkir. 2018. The Internal Control of Management Accounting Information Systems of the State-Owned Enterprises in Indonesia. Archives of Business Research 6(6).

Damayanti, K. dan Fardinal. 2019. The Effect of Information Technology Utilization, Management Support, Internal Control, and User Competence on Accounting Information System Quality (Study on Finance Company in Jakarta). Schollars Bulletin 5(12): 754-761.

Darma, J., A. Susanto, S. Mulyani, dan J. Suprijadi. 2018. The Role of Top Management Support in the Quality of Financial Accounting Information Systems. Journal of Applied Economic Sciences 13(4): 1009-1020.

Darma, J. dan G. H. Sagala. 2020. Pengaruh Kualitas Sistem Informasi Akuntansi Terhadap Kualitas Informasi Akuntansi. Jurnal Ilmiah MEA (Manajemen, Ekonomi, $\mathcal{E}$ Akuntansi) 4(1): 227-237.

Dehghanzade, H., M. A. Moradi, dan M. Raghibi. 2011. A Survey of Human Factors' Impacts on the Effectiveness of Accounting Information Systems. Inter- national Journal of Business Administration 2(4): 166-174.

Dwivedi, Y. K., D. Wastell, S. Laumer, H. Z. Henriksen, M. D. Myers, D. Bunker, A. Elbanna, M. N. Ravishankar, dan S. C. Srivasta. 2014. Research on Information Systems Failures and Successes: Status Update and Future Directions. Information Systems Frontiers 17(1): 143157.

Effendi, Y. A. dan N. Nuzulita. 2019. Process Discovery of Business Processes Using Temporal Causal Relation. Journal of Information Systems Engineering and Busines Intelligence 5(2): 183-194.

Endraria, E. 2019. Quality of Accounting Information Systems for Facing Industrial Revolution Is Influenced by Business Process and Organizational Commitment. Canadian Social Science 15(6): 23-30.

Eryana, D. dan Fardinal. 2019. Effects of Organizational Commitment and Internal Control on Accounting Information System Quality and Its Impact on Accounting Information Quality (Research on Trading Companies listed in PT. Solusi Akuntansi Indonesia). Scholars Bulettin 5(12): 734-742.

Farhanghi, A. A., A. Abbaspour, dan R. A. Ghassemi. 2013. The Effect of Information Technology on Organizational Structure and Firm Performance: an Analysis of Consultant Engineers Firms $(\mathrm{CEF})$ in Iran. Procedia-Social and Behavioral Sciences 81: 644-649.

Fitriati, A. dan S. Mulyani. 2015. Factors that Affect Accounting Information Systems Success and Its Implication on Accounting Information Quality. Asian Journal of Information Technology 14(5): 154-161.

Fitrios, R. 2016. Factors that Influence Accounting Information System Implementation and Accounting Information Quality. International Journal of Scientific $\mathcal{E}$ Technology Research 5(4): 192-198.

Fransisca, E., Y. Carolina, dan Rapina. 2020. How to Improve the Quality of Accounting Information Systems from Organi- 
zational Perspective (Empirical Evidence from Banking Sector in BandungIndonesia). International Conference on Global Innovation and Trends in Economy 3(1): 769-782.

Gross, J. 2011. Two Causes of ERP Implementation Failure (and How to Avoid Them). https://www.pemeco.com/ mitigate-two-key-erp-implementationfailure-risks-to-drive-erp-success/. Diakses Tanggal 13 September 2020.

Hair, J. F., G. T. M. Hult, C. M. Ringle, dan M. Sarstedt. 2014. A Primer on Partial Least Squares Structural Equation Modeling (PLS-SEM). Sage Publications, Inc. USA.

Halimatusadiah, E., N. Nurhayati, dan E. R. Rayandani. 2015. Effects of Top Management Support, Education and Training on the Effectiveness of Accounting Information System (Survey on Government-Owned Insurance Companies in Bandung). International Journal of Managerial Studies and Research (IJMSR) 3(10): 87-90.

Hall, J. A. 2011. Accounting Information Systems. 7e. South Western Cengage Learning. USA.

Hartarto, A. 2018. Making Indonesia 4.0: Strategi RI Masuki Revolusi Industri Ke4. https://www.kemenperin.go.id/artikel/ 18967/Making-Indonesia-4.0:-Strategi-RIMasuki-Revolusi-Industri.

Diakses Tanggal 13 September 2020.

Heinrich, R., P. Merkle, J. Henss, dan B. Paech. 2017. Integrating Business Process Simulation and Information System Simulation for Performance Prediction. Software \& Systems Modeling 16(1): 257-277.

Hernanda, L. T. dan H. Setiyawati. 2020. Pengaruh Komitmen Organisasi, Pelaksanaan Anggaran Dan Implementasi Sistem Informasi Akuntansi Terhadap Kualitas Laporan Keuangan (Survei pada Pemerintah Daerah Kota Bogor). Al-Mal: Jurnal Akuntansi dan Keuangan Islam 1(2): 115-129.

Hertati, L. dan W. Zarkasy. 2015. Effect of Competence User Information System, the Quality of Accounting Information Systems Management and Implications Insatisfaction User Information System (State Owner in Sumatera Selatan). European Journal of Accounting, Auditing and Finance Research 3(2): 35-60.

Hertati, L., O. Safkaur, dan A. M. Simanjuntak. 2020a. How to Align Management Commitments to the Successful Implementation of Management Accounting Information Systems in Manager Decision Making. Ilomata International Journal of Tax and Accounting 1(2): 89-102.

Hertati, L., Nazarudin, dan I. Fery. 2020b. Top Management Support Functions in Higher Education Management Accounting Information Systems. Ilomata International Journal of Tax $\mathcal{E}$ Accounting 1(4): 210-224.

Hidayat, A. 2015. MK: BI, OJK, LPS Harus Punya Sistem Informasi Terintegrasi. https://m.tempo.co/read/news/2015/08/04/0 87689081/mk-bi-ojk-lps-harus-punyasistem-informasi-terintegrasi.

Hiyari, A., M. H. Mashregy, dan N. K. Mat. 2013. Factors that Affect Accounting Information System Implementation and Accounting Information Quality: a Survey in University Utara Malaysia. American Journal of Economics 3(1): 27-31.

Hla, D. dan S. P. Teru. 2015. Efficiency of Accounting Information System and Performance Measures-Literature Review. International Journal of Multidisciplinary and Current Research 3: 976-984.

Huang, S. Y., C. H. Lee, dan A. A. Chiu. 2015. How Business Process Reengineering Affects Information Technology Investment and Employee Performance under Different Performance Measurement. Information Systems Frontiers 17(5): 1133-1144.

Huy, P. Q. dan V. K. Phuc. 2020. Accounting Information System in the Era of Industry 4.0 - an Exploratory Study at Public Sector. International Journal of Disaster Recovery and Business Continuity 11(1): 838-849. 
Iskandar, D. 2015. Analysis of Factors Affecting the Success of the Application of Accounting Information System. International Journal of Scientific \& Technology Research 4(2): 155-162.

Kabugo, D. 2011. Does Personality Type Affect Teachers' Information Systems Utilization in Pedagogy? The Makerere University Lecturers' Experience. IFIP Conference on Information Technology in Educational Management 348: 156-165.

Khan, M. R. F., N. A. Lahad, dan S. Miskon. 2014. Exploring the Influence of Big Five Personality Traits towards Computer Based Learning (CBL) Adoption. Journal of Information Systems Research and Innovation 8: 1-8.

Khechine, H. dan S. Lakhal. 2018. Technology as a Double-Edged Sword: from Behavior Prediction with Utaut to Students' Outcomes Considering Personal Characteristics. Journal of Information Technology Education: Research 17: 63-99.

Kloviene, L. dan E. Gimzauskiene. 2015. The Effect of Information Technology on Accounting System's Conformity with Business Environment: a Case Study in Banking Sector Company. Procedia Economics and Finance 32: 1707-1712.

Komala, A. R. 2012. The Influence of the Accounting Manager's Knowledge and the Top Managements' Support on the Accounting Information System and Its Impact on the Quality of Accounting Information: a Case of Zakat Institutions in Bandung. Journal of Global Management 4(1): 53-73.

Kosti, M. V., R. Feldt, dan L. Angelis. 2014. Personality, Emotional Intelligence and Work Preferences in Software Engineering: an Empirical Study. Information and Software Technology 56(8): 973-990.

Kuraesin, A. D., W. Yadiati, M. Sueb, dan T. Fitrijanti. 2019. The Effect of Management Support on the Quality of Accounting Information Systems and Its Impact on the Quality of Accounting Information (in Private Higher Education in Bandung City). International Journal of
Mechanical Engineering and Technology 10(3): 450-456.

Lakhal, S. dan H. Khechine. 2017. Relating Personality (Big Five) to the Core Constructs of the Unified Theory of Acceptance and Use of Technology. Journal Computers in Education 4(3): 251282.

Laudon, K. C. dan J. P. Laudon. 2012. Management Information Systems: Managing the Digital Firm. Twelfth Edition. Pearson Education, Inc. USA.

Laumer, S., C. Maier, dan A., Eckhardt. 2014. The Impact of Human Resources Information Systems and Business Process Management Implementations on Recruiting Process Performance: a Case Study. 20th Americas Conference on Information Systems, AMCIS 2014.

Lea, B., K. Yu, A. Engelke dan C. Koob. 2019. Big Five Personality Traits in Learning Complex Information Systems: a Case Study. Issues in Information Systems 20(4): 107-115.

Legner, C., T. Eymann, T. Hess, dan C. Matt. 2017. Digitalization: Opportunity and Challenge for the Business and Information Systems Engineering Community. Business \& Information Systems Engineering 59(4): 301-308.

Lestari, R. dan L. Hertati. 2020. Bagaimana Pengaruh Strategi Bisnis, Kekuatan Produk terhadap Kualitas Sistem Informasi Akuntansi Manajemen: Studi Kasus pada Usaha Kecil dan Menengah di Indonesia. Kajian Akuntansi 21(1): 0116.

Lingga, I. S. 2021. Analysis of Organizational Commitment in Determining the Success of Accounting Information Systems (AIS) in the Banking Sector. The Indonesian Accounting Review 11(1): 9-19.

Maier, C. 2012. Personality within Information Systems Research: A Literature Analysis. ECIS 2012 Proceedings. 101.

Meiryani dan M. Syaifullah. 2015. Influence Business Process on the Quality of Accounting Information System. 
International Journal of Scientific $\mathcal{E}$ Technology Research 4(01): 323-328.

Meiryani, A. Susanto, dan D. L. Warganegara. 2019. The Issues Influencing of Environmental Accounting Information Systems: An Empirical Investigation of SMEs in Indonesia. International Journal of Energy Economics and Policy 9(1): 282290.

Meiryani, S. Leny, S. Jajat, dan S. Mat Zaidi. 2020. Accounting Information Systems as a Critical Success Factor for Increased Quality of Accounting Information. Revista Espacios 41(15).

Mekinjić, B. 2019. The Impact of Industry 4.0 on the Transformation of the Banking Sector. Journal of Contemporary Economics 1(1): 6-28.

Mulyani, S. 2015. Metode Analisis dan Perancangan Sistem. Abdi Sistematika. Bandung.

Mulyani, S. 2018. Kata Sri Mulyani Soal Peranan Perbankan dalam Mendorong Ekonomi RI. https://www.liputan6.com/ bisnis/read/3526017/kata-sri-mulyani-soalperanan-perbankan-dalam-mendorongekonomi-ri. Diakses Tanggal 13 September 2020.

Murtadho, M. F., N. Nurhayati, dan E. Halimatusadiah. 2018. Pengaruh Kompetensi Pengguna dan Dukungan Manajemen Puncak terhadap Kualitas Sistem Informasi Akuntansi (Survei pada Cabang Bank BJB Syariah di Kota dan Kabupaten Bandung). Kajian Akuntansi 19(1): 29-36.

Morley, D. dan C. Parker. 2015. Understanding Computers: Today and Tomorrow, Comprehensive. 15th edition. Course Technology, Cengage Learning. USA.

Napitupulu, I. H. 2018. Organizational Culture in Management Accounting Information System: Survey on Stateowned Enterprises (SOEs) Indonesia. Global Business Review 19(3): 556-571.

Nurhayati, N. 2014. Influence of Organizational Commitment and Knowledge Management on Successful Implementation of Accounting Infor- mation Systems in the Employer Pension Funds Held Defined Benefit Pension Plan (PPMP) Dipropinsi West Java, Indonesia. International Journal of Economics, Commerce and Management II(12): 1-16.

Nurhayati, N. dan S. Mulyani. 2015. User Participation on System Development, User Competence and Top Management Commitment and Their Effect on the Success of the Implementation of Accounting Information Systems. European Journal of Business and Innovation Research 3(2): 56-68.

Nurhayati, N. dan N. Koesdiningsih. 2018. The Effectiveness of Financial Accounting Information System with Approach of Organizational Culture and User Competency in Baznas North of West Java. The 2018 International Conference of Organizational Innovation, KnE Social Sciences: 944-956.

Nurhayati, N. dan A. Susanto. 2017. The Influence of Transformational Leadership on the Success of Accounting Information Systems Implementation (Survey on National Zakat Management Institution of West Java). Journal of Engineering and Applied Sciences 12(17): 4534-4539.

Nurliyani, J. Darma, dan A. Ikhsan. 2020. The Effect of Organizational Culture on the Quality of Accounting Information Systems. Budapest International Research and Critics Institute (BIRCI-Journal) 3(1): 198-205.

Nusa, I. B. S. 2015. Influence of Organizational Culture and Structure on Quality of Accounting Information System. International Journal of Scientific $\mathcal{E}$ Technology Research 4(5): 257-267.

O'Brien, J. A. dan G. M. Marakas. 2011. Management Information Systems. Tenth Edition. McGraw-Hill/Irwin. NewYork.

Okab, R., dan M. A. Al-Oqool. 2014. The Role of Accountants in E-accounting Information Systems' Lifecycle at the Jordanian Banking Sector. International 
Journal of Business and Social Science 5(4): 265-279.

Puspitawati, L. dan S. D. Anggadini. 2019. The Influence of the Quality Accounting Information System to the Quality of Accounting Information - Evidence In Indonesia. Majalah Ilmiah Unikom 17(1): 3-12.

Puspitawati, L. dan M. Wisdayanti. 2020. Kesuksesan Sistem Informasi Akuntansi yang Dipengaruhi oleh Optimalisasi Dukungan Manajemen Puncak serta Efektifitas Struktur Organisasi. Jurnal Riset Akuntansi \& Keuangan 8(3): 531-540.

Rachmawati, R. 2016. Struktur Organisasi, Pengendalian Intern Terhadap Kualitas Sistem Informasi Akuntansi Manajemen. MIX: Jurnal Ilmiah Manajemen VI(1): 70-82.

Rachmawati, S. D. dan F. Fardinal. 2017. Pengaruh Aktivitas Pengendalian, Informasi dan Komunikasi terhadap Kualitas Sistem Informasi Akuntansi dan Dampaknya terhadap Kualitas Laporan Keuangan (Studi Kasus pada Badan Pemeriksa Keuangan Republik Indonesia). Profita: Komunikasi Ilmiah dan Perpajakan 10(3): 426-437.

Rahayu, S. K. 2012a. The Factors that Support the Implementation of Accounting Information System: a Survey in Bandung and Jakarta's Tax Payer Offices. Journal of Global Management 4(1): 25-52.

Rahayu, S. K. 2012b. The Influence of Organizational Culture and Organizational Structure to Implementation of Accounting Information System in Public Sector (Survey in Small Taxpayers Office in Bandung and Jakarta). Majalah Ilmiah UNIKOM 10(1): 123-142.

Rahayu, S. K., L. Puspitawati, dan S. D. Anggadini. 2014. Analisis Budaya Organisasi pada Pengembangan Sistem Informasi di Unikom. Majalah Ilmiah UNIKOM 12(2): 203-210.

Ramazani, M. dan A. Allahyari. 2013. Compatibility and Flexibility of
Accounting Information Systems. Journal of Emerging Trends in Computing and Information Sciences 4(3): 290-295.

Rapina, R. dan A. Susanto. 2017. An Empirical Investigation of the Accounting Information Systems Quality. Advanced Science Letters 23(11): 1162911633.

Rapina. 2017. The Influence of Leadership and Organizational Structure on the Quality of Accounting Information System. Accounting and Finance Review 2(3): 58-63.

Rapina R. dan B. Hadianto. 2019. The Effect of Business Process on Accounting Information Quality through Accounting Information System Quality. International Journal of Research and Analytical Reviews 6(1): 1032-1036.

Rapina, R., Y. Carolina, S. Setiawan, C. Maria, dan M. Puspita. 2020. The Success of Accounting Information Systems Observed from Individual and Organizational Factors. TEST Engineering \& Management 82: 6011-6016.

Ruiz, C., D. Costal, S. Espania, dan O. Pastor. 2015. GoBIS: an Integrated Framework to Analyse the Goal and Business Process Perspectives. Information Systems 53: 330-345.

Salehi, M. dan A. Abdipour. 2013. Accounting Information System's Barriers: Case of an Emerging Economy. African Journal of Business Management 7(5): 298-305.

Sari, E. N. 2018a. The Successful Implementation of Accounting Information Systems and the Quality of Government Financial Statements at Regencies and Cities in North Sumatra, Indonesia. International Business Management 12(4): 346-352.

Sari, N. Z. M. 2018b. The Effect Business Process to Quality of Accounting Information Systems with Survey in BUMN Industrial Strategies in Bandung Indonesia. International Journal of Trend in Research and Development 5(6): 1-4.

Sari, N. Z. M., A. Susanto, N. N. Afiah, M. Sueb, dan H. Suharman. 2019. Supply 
Chain Quality Accounting Information Systems with Business Strategy Effective in BUMN Bandung Indonesia. International Journal of Supply Chain Management 8(6): 81-86.

Sekaran, U. dan R. Bougie. 2016. Research Methods for Business: A Skill Building Approach. John Wiley \& Sons. UK.

Susetyo, D. P., D. Sadeli, dan S. Surtikanti. 2016. Dukungan Manajemen Puncak, Kemampuan Teknik, Pelatihan Karyawan dan Kinerja Sistem Informasi Akuntansi Perbankan. Jurnal Riset Akuntansi dan Perpajakan (JRAP) 3(01): 109-120.

Taherdoost, H. dan A. Keshavarzsaleh. 2015. A Theoretical Review on IT Project Success/Failure Factors and Evaluating the Associated Risks. 14th International Conference on Telecommunications and Informatics.

Trigo, A., F. Belfo, dan R. P. Estebanez. 2016. Accounting Information Systems: Evolving towards a Business Process Oriented Accounting. Procedia Computer Science 100: 987-994.

Triyaminanti, N. 2017. Pengaruh Struktur Organisasi dan Budaya Organisasi terhadap Kualitas Sistem Informasi Akuntansi pada PT. KAI DAOP 2 Bandung. Jurnal Akuntansi, Audit, dan
Sistem Informasi Akuntansi (JASa) 1(1): 92-104.

Velarosdela, R. N. 2020. Pembobolan Rekening Ilham Bintang, Libatkan Karyawan Bank hingga Pembuatan KTP Palsu. https://megapolitan.kompas.com/ $\mathrm{read} / 2020 / 02 / 06 / 08145841 /$ pembobolanrekening-ilham-bintang-libatkan-karyawanbank-hingga-pembuatan?page=all. Diakses Tanggal 13 September 2020.

Warren, J. D., K. C. Moffitt, dan P. Byrness. 2015. How Big Data Will Change Accounting. Accounting Horrizons 29(2): 397-407.

Wijaya, I. N. A., I. S. Lingga, Debbianita dan Maria. 2021. Analyze Factors that Affect Entrepreneurs of Micro, Small, Medium Enterprises Intention to Use Accounting Information Systems Based on Flow Theory. Accounting Research Journal of Sutaatmadja 5(01): 54-62.

Wisna, N. 2016. Improving Quality of Accounting Information through Transformational Leadership: a Review. International Business Management 10(12): 2406-2412.

Yilmaz, M., R. V. O. Connor, R. C. Palacios, dan P. Clarke. 2017. An Examination of Personality Traits and How They Impact on Software Development Teams. Information and Software Technology 86: 101-122. 